\title{
Thermal Efficiency of a Solar Wall in Tunisia
}

\author{
Narjes Dimassi and Leila Dehmani \\ Laboratoire des Procédés Thermiques, Centre de Recherches et des Technologies de l'Energie, Technopôle de Borj-Cédria, \\ BP 95, 2050 Hammam-Lif, Tunisia \\ Correspondence should be addressed to Narjes Dimassi, dimassinarjes@yahoo.fr
}

Received 9 April 2012; Accepted 9 May 2012

Academic Editors: J. Kaldellis and K. T. Lee

Copyright () 2012 N. Dimassi and L. Dehmani. This is an open access article distributed under the Creative Commons Attribution License, which permits unrestricted use, distribution, and reproduction in any medium, provided the original work is properly cited.

\begin{abstract}
Passive solar heating systems are very attractive because of their exploitation of solar energy which is available and abundant. A passive solar system contributes with storage and direct gain to heat a building without the use of mechanical equipment. This investigation is a verification of the Trombe wall efficiency in Tunisia via an experimental study on a real building with a specificity of the local weather. The experimental study was carried on a south wall under real scale in the laboratory of thermal processes in the Center of Research and Technology of Energy (CRTEn) in Borj Cedria. During two different winter periods (January and April), the thermal performance of the wall was investigated using the collected data of velocity and temperature at different positions of the wall. The heat gain through the wall was calculated and the efficiency was found to decrease from January period (45\%) to April period (31.7\%). The results show that the Trombe wall ensures free heat in winter and can greatly increase the energy efficiency of a building. Thus, the Trombe wall integration to the building design offers many opportunities to take advantage of the Tunisian moderate climate.
\end{abstract}

\section{Introduction}

Solar passive systems have been used as alternatives to fossil fuels for space-heating applications with the purpose of a greatest exploitation of solar energy. One such system, known as the Trombe wall, has been studied for residential applications. The Trombe wall consists of a south-facing glazing installed at a small distance from a massive wall with two vents and made of concrete or masonry coated with dark. Solar radiation passes through the glazing and strikes on the black wall which absorbs solar radiation with high efficiency and warms up the air. Solar heat is transferred into the room by two ways: conduction through the wall and natural convection by air flow between the indoor air and the air gap through wall vents. Trombe wall system was first developed by an American named Edward Morse in 1881 [1] and revived by the French inventor Felix Trombe [2]. Today Trombe walls are more attractive in order to reduce the energy consumption. Many investigations have focused on the numerical study of conduction and natural convection through the Trombe wall to treat its thermal performance [35]. Other theoretical and experimental studies have shown that the indoor comfort is improved as well as reduction in annual heating energy due to well-designed Trombe walls [6-8]. Balcomb [9] showed that it is an effective technology for reducing heating energy, as much as $47 \%$ in residential cases. Zalewski et al. [10] proposed a composite Trombe wall and they tested it experimentally. Jie et al. [11] proposed an improved Trombe wall to be adapted to building constructions with selective thermoinsulation façades. They affirmed that the operating efficiency of the improved Trombe wall can be up to $33.85 \%$ which represents an increase of $56 \%$. Stazi et al. [12] carried out a series of monitoring campaigns in different seasons and dynamic simulations with the software EnergyPlus in order to investigate the Trombe wall's thermal behavior. They evaluated the solar wall's influence on heating and cooling energy needs and the indoor thermal comfort and optimized the solar wall's behavior by varying the envelope insulation level. Koyunbaba et al. [13] have carried out an energy analysis for determining the performance of a BIPV Trombe wall integrated to a room façade. They showed that the experimental daily average electrical and thermal efficiency of this system can reach, respectively, $4.52 \%$ and $27.2 \%$. 
Sandbergh and Moshfegh [14] presented temperature data for flow in a ventilated PV channel, comparing two different geometries for the outlet from the channel. Hirunlabh et al. [15] monitored the ventilation due to a thermosyphoning air panel in Bangkok.

The Tunisian climate is mild and characterized by abundant solar radiation around the year but it presents an important need of heating in winter, consequently the building sector in Tunisia is the largest energy consumer. Thus, the concept of solar walls, which could be a perfect solution, is rarely used in the Tunisian building architecture. In this paper, the heat gain through Trombe wall, for winter heating, on a real building in Borj Cedria, a city in the south region of Tunis was investigated. An experimental setup was displayed to treat the thermal response of the wall. Then, conductive and convective fluxes and thermal efficiency were calculated and compared for two different winter periods.

\section{Experimental Setup}

2.1. Case Study. The case study is an office including on the south-facing a Trombe wall and belongs to a building in the Center of Research and Technology of Energy (CRTEn) in Borj Cedria (south of the golf of Tunis, $36^{\circ} 43^{\prime} 04^{\prime \prime} \mathrm{N}$, $\left.10^{\circ} 25^{\prime} 41^{\prime \prime} \mathrm{E}\right)$. The location is characterized by a mild Mediterranean climate with relatively cold winters and hot summers. Figure 1 shows the monthly distribution of the solar heat flux and the ambient temperature (average of 4 years 2007-2011) recorded by the weather station-type NRG implanted in CRTEn.

2.2. Experiment Description. Figure 2 gives a schematic diagram of the studied Trombe wall. The $0.23 \mathrm{~m}$ thick wall was made of brick and mortar construction and faced to the south. The exterior wall surface was blackened and measured $1.95 \mathrm{~m} \times 1.5 \mathrm{~m}$. Two pairs of rectangular vents, each of $0.2 \mathrm{~m}$ $\times 0.6 \mathrm{~m}$ were located near the base and the top of the wall. The glazing was located $0.16 \mathrm{~m}$ in front of the wall. The air is heated in contact with the brick wall, rises and circulates towards the room by the upper vent. Heat is also collected and stored in the thick concrete dark wall and released to the room by conduction.

The different temperatures were measured using chromel-alumel thermocouples located at different positions of the wall surface to get an average temperature. Thermocouples were calibrated to within $\pm 0.2^{\circ} \mathrm{C}$ at $0^{\circ} \mathrm{C}, 30^{\circ} \mathrm{C}$, and $70^{\circ} \mathrm{C}$. The uncertainty of the temperature measurements is estimated to be less than $\pm 0.3^{\circ} \mathrm{C}$. During the temperature record, the environmental conditions influencing the wall operation were measured. The solar radiation was recorded by a KIPP-ZONEN CMP 21 Pyranometer (accuracy $\pm 10 \mathrm{~W} / \mathrm{m}^{2}$ ), and the wind speed was measured by an anemometer LITTOCLIME (13N-219-S34) with a calibrated accuracy of $\pm 0.5 \mathrm{~m} / \mathrm{s}$. The outdoor air temperature and humidity were measured using a temperature and humidity transmitter (HD 9008TR). The temperature and humidity precision are, respectively, $\pm 0.15^{\circ} \mathrm{C}$ and $\pm 2 \% \mathrm{HR}$. All these instruments were connected to an Agilent (HP34970A) data acquisition
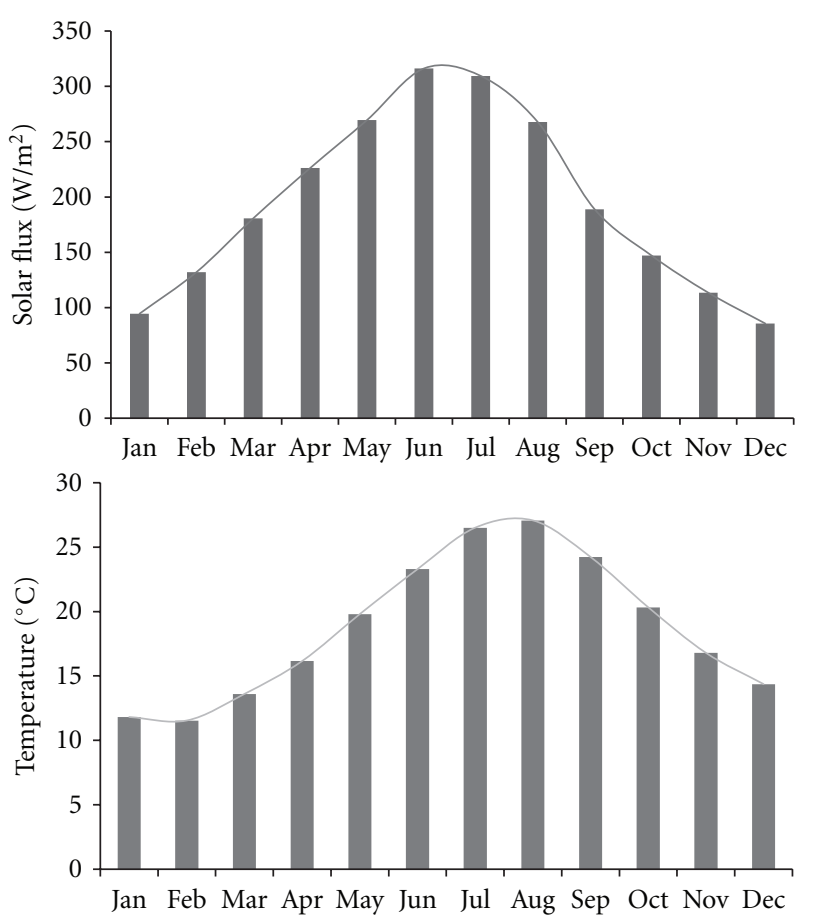

FIGURE 1: The monthly distribution of the: (a) solar flux; (b) ambient temperature, weather station of Borj Cedria, average of 4 years (2007-2011).

system. The velocity measurements at the upper vent of the wall were recorded by a Testo 435 anemometer probe (accuracy $\pm 0.01 \mathrm{~m} / \mathrm{s}$ ).

\section{Results}

Experiments were performed over the heating season. Two typical periods were studied, one at the beginning and one at the end of winter. These periods are characterized by a cold and wet weather, where heating is necessary to achieve comfort conditions. In this context, the climatic data influencing the thermal behavior of the Trombe wall were developed.

\subsection{Climatic Data}

3.1.1. Period from 22nd January 2010 to 25th January 2010. Figure 3 shows the evolution of outdoor air temperature and solar radiation during three days from 22th January to 25th January and every peak corresponds with a new day. The outdoor air temperature maximum $\left(21^{\circ} \mathrm{C}\right)$ is obtained on $23 / 1 / 2010$ at $13: 30$ and the minimum is about $6^{\circ} \mathrm{C}$ observed on $24 / 1 / 2010$ at 2:37. The solar radiation on the wall was characterized by many heavy climatic disturbances which induce great variations of solar radiation intensity and a mean value that exceeds $800 \mathrm{~W} / \mathrm{m}^{2}$ was observed. The incident solar energy amount on the wall allows a good operation of the Trombe wall during winter. April 2010 to 9th April 2010 (Figure 4), the sun was available 


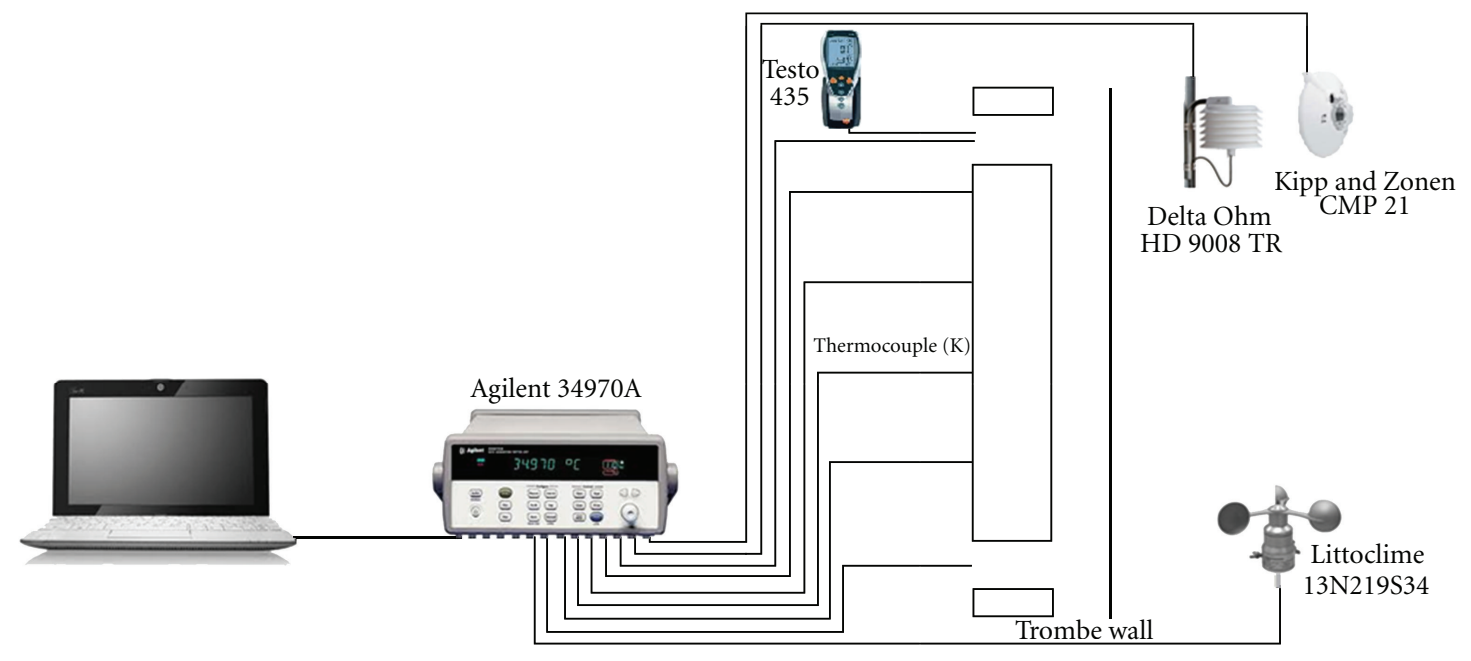

FIgURE 2: Schematic diagram of the expirement.

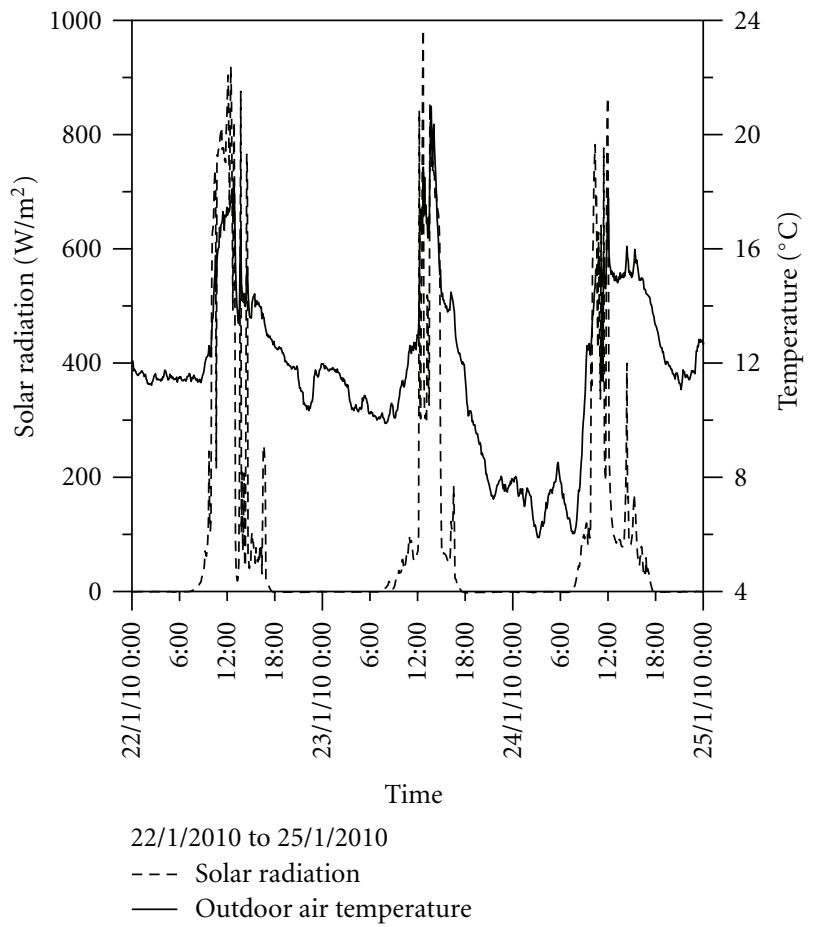

Figure 3: Climatic data from 22nd January 2010 to 25th January 2010.

most of the time and the evolution of solar radiation shows many fluctuations due to the cloudy weather characteristics and only one overcast day was observed at the end (8th April 2010). Recorded values of the incident solar radiation on the wall were quite low comparing to those of January period and the maximum reached only $258 \mathrm{~W} / \mathrm{m}^{2}$ on 7 th April 2010 at 11:30. This is due to the change of sun trajectory with regard to months on the southern wall. The outside

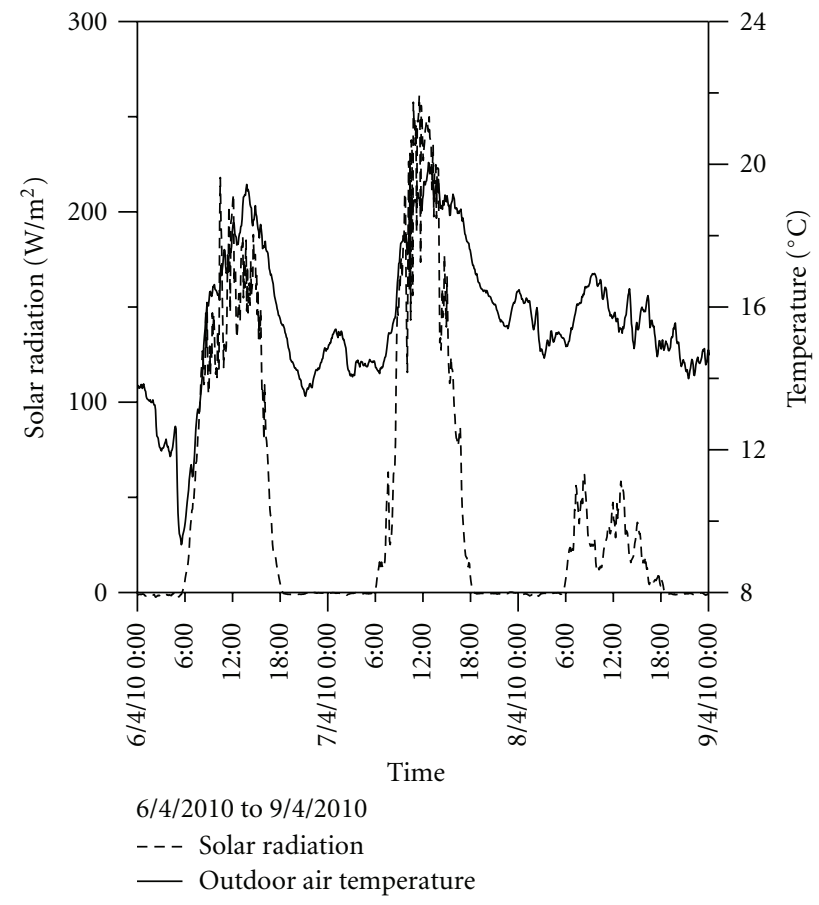

FIgure 4: Climatic data from 6th April 2010 to 9th April 2010.

temperature ranged from $9.5^{\circ} \mathrm{C}$ (night minimum) to $20^{\circ} \mathrm{C}$ (day maximum) which shows a cold period where there are heating requirements.

3.2. Thermocirculation. The thermocirculation process occurs through the Trombe wall vents. To highlight this phenomenon, the evolution of vents air temperature and indoor air temperature of the two periods described previously was plotted. 


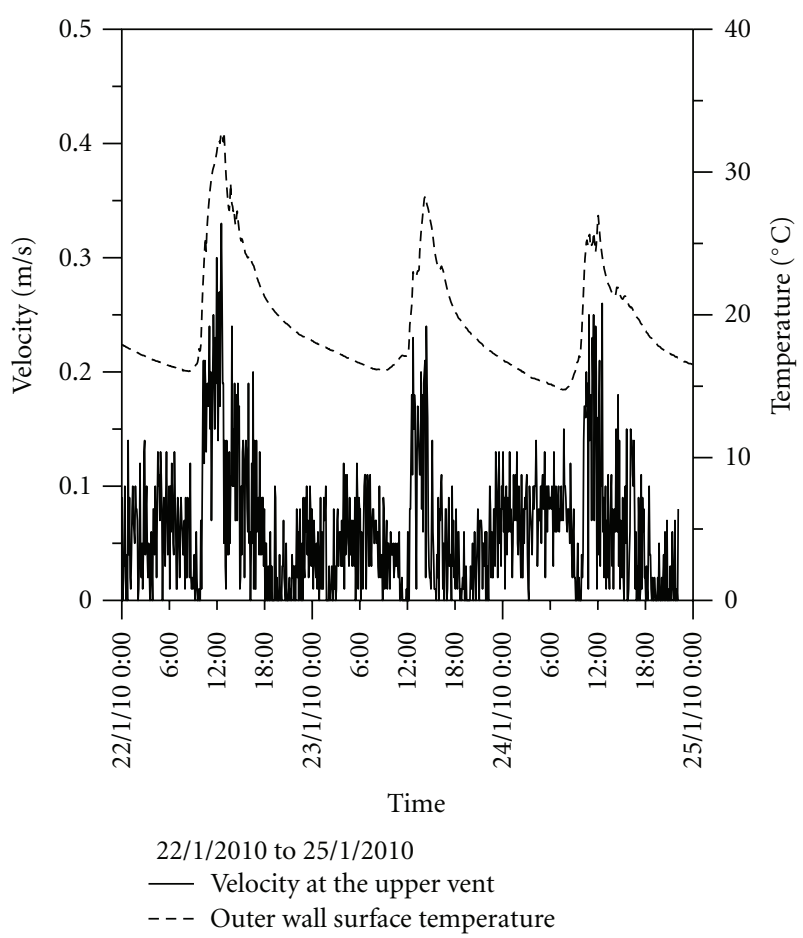

Figure 5: Evolution of the velocity at the upper vent and outer surface of the wall for January period.

3.2.1. Period from 22nd January 2010 to 25th January 2010. Figure 5 shows the evolution of velocity at the upper vent and the outer wall surface temperature for the studied period. At sunrise, 3 peaks were observed: every peak of wall surface temperature corresponds to a peak of air velocity at the upper vent which reaches a mean maximum of $0.25 \mathrm{~m} / \mathrm{s}$ on 22 January 2010. This indicates the occurrence of the thermocirculation process. In fact, the air closer to the blackened wall surface is heated by radiation and convection causing its density decrease; therefore, the air rises, until it reaches the room through the upper vent. Figure 6 shows the temperature evolution of the upper and the lower vent of the wall and the indoor air temperature. For this period, characterized by a low outdoor air temperature, the comfort conditions are reached in the room, with regard to the indoor air temperatures values which ranged from $18^{\circ} \mathrm{C}$ to $19^{\circ} \mathrm{C}$. On $22 / 1 / 2010$, the upper vent air temperature is quite equal to $25^{\circ} \mathrm{C}$ and the lower vent is cooler and equal to $16^{\circ} \mathrm{C}$, which gives a difference of $9^{\circ} \mathrm{C}$ and represents a significant free heat gain. Another exceptional phenomenon was observed on 24 January 2010, early in the morning. In fact, at 2:30, the outdoor air temperature dropped to $6.5^{\circ} \mathrm{C}$, at the same time, the recorded vent air temperature was $13^{\circ} \mathrm{C}$ at the lower vent and $15^{\circ} \mathrm{C}$ at the upper vent. As a result, the decrease of outdoor air temperature has a cooling effect on the air gap so the wall becomes cooler than the room and an inverse air circulation takes place. The air escapes from the upper vent to the air gap and returns to the room through the lower vent. This phenomenon is called the inverse thermocirculation.

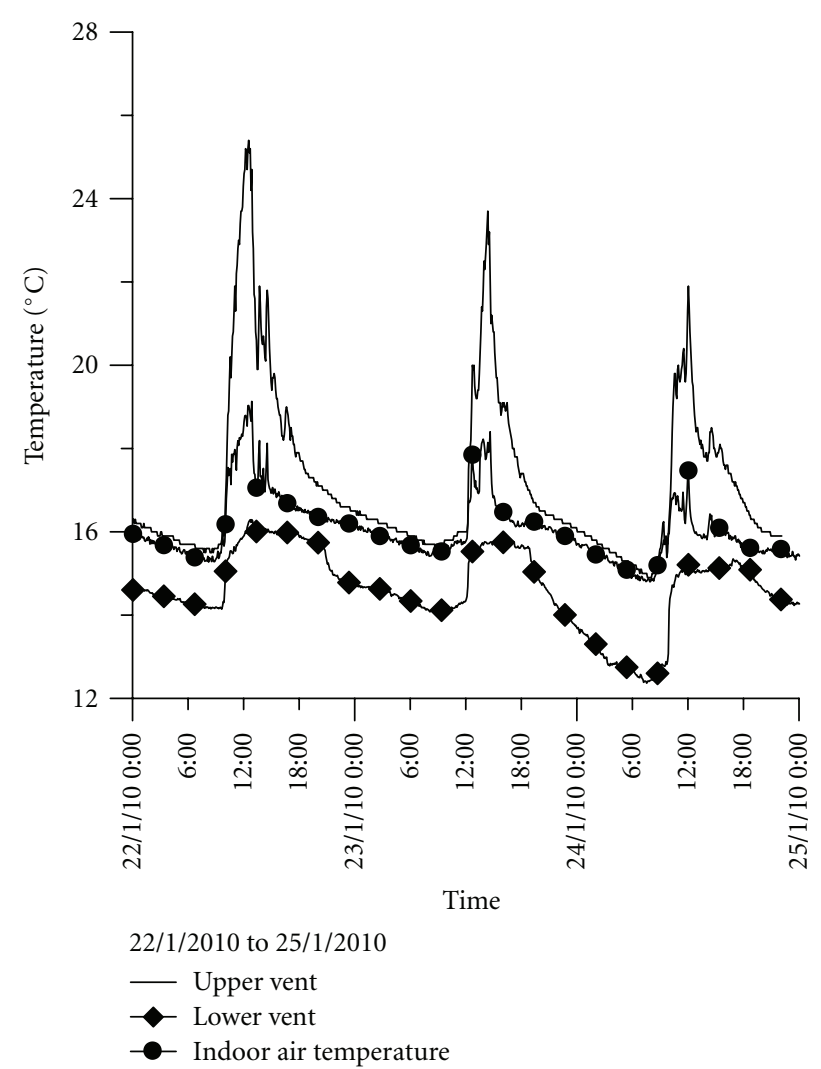

Figure 6: Evolution of vents air temperature and indoor air temperature for January period.

3.2.2. Period from 6th April 2010 to 9 th April 2010. Figure 7 shows the evolution of velocity at the upper vent and the outer surface temperature of the wall for April period. As excepted, the wall temperature and the upper vent velocity depends on solar radiation. In fact, the maximum air velocity $(0.4 \mathrm{~m} / \mathrm{s})$ is observed on 7 April 2010 which is the sunniest day of the studied period, for this day, the exterior temperature of the wall reaches a maximum of $25.5^{\circ} \mathrm{C}$. Conversely, in January period the outer wall surface temperature exceeds $30^{\circ} \mathrm{C}$ which reveals that January environmental conditions especially the sun position are more favorable for the Trombe wall operation.

Figure 8 shows the evolution of vents air temperature and the indoor air temperature for April period. Although there is a difference in temperature between the two periods investigated (January and April) the same Trombe wall thermal behavior was observed and this wall contributes to indoor air temperature increase through the upper vent.

\subsection{Conduction}

3.3.1. Period from 22nd January 2010 to 25th January 2010. Figure 9 shows the Trombe wall outer and inner average surface temperatures and the indoor air temperature. The outer wall surface temperature maximum $\left(32.7^{\circ} \mathrm{C}\right)$ is obtained on 22 January 2010 at $12: 30$. The inner surface temperature which has never received solar radiation reaches a maximum 


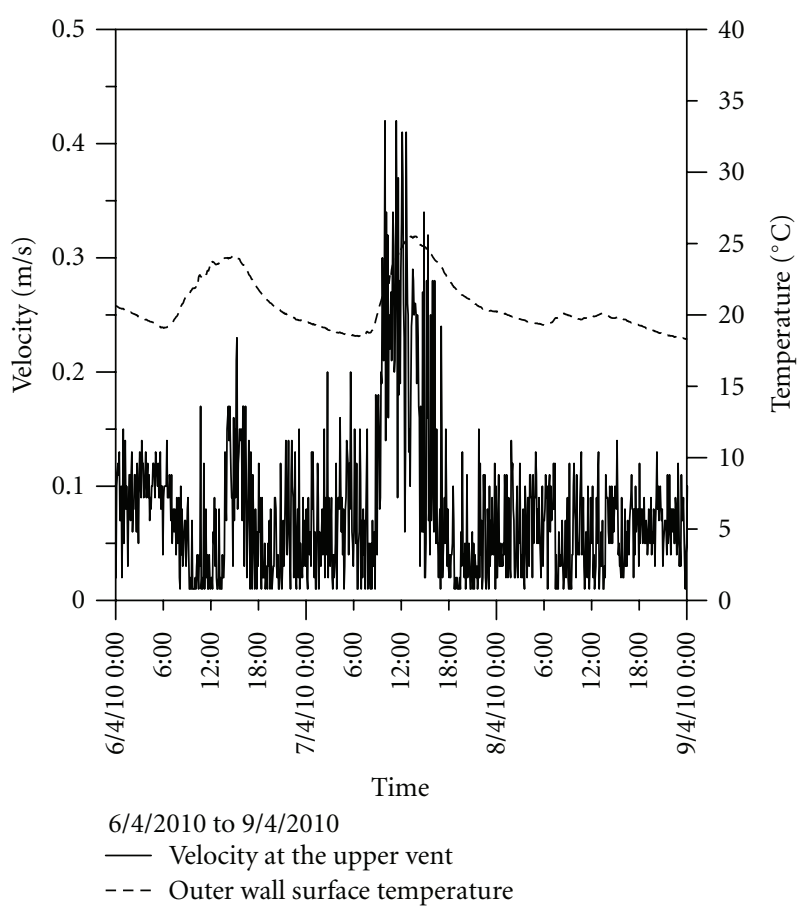

Figure 7: Evolution of the velocity at the upper vent and outer surface temperature of the wall for April period.

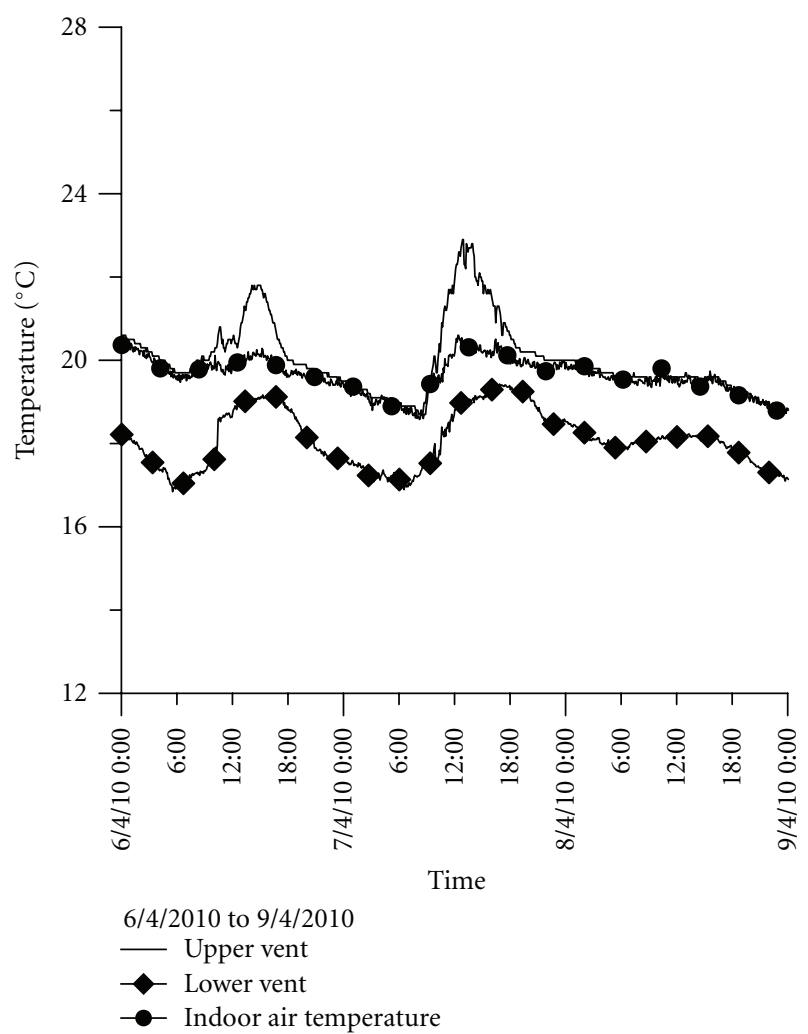

FIGURE 8: Evolution of vents air temperature and indoor air temperature for April period.

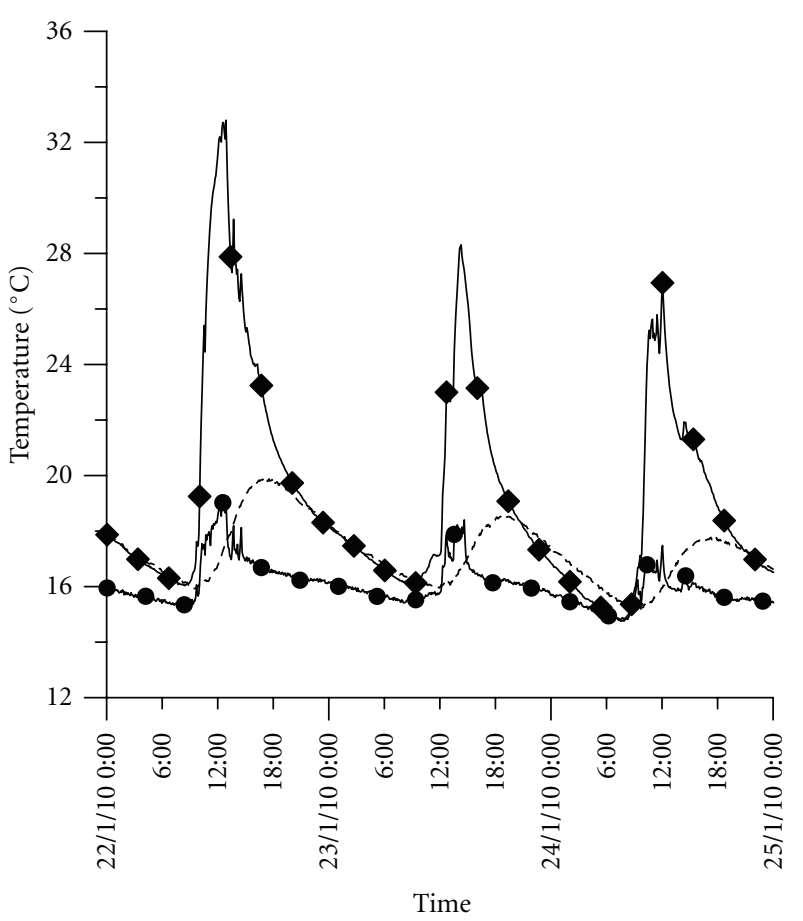

$22 / 1 / 2010$ to $25 / 1 / 2010$

- - - Inner wall surface temperature

- Outer wall surface temperature

- Indoor air temperature

FIGURE 9: Temperature variations of indoor air temperature and thermal wall surfaces temperatures for January period.

of $20.6^{\circ} \mathrm{C}$ at $18: 30$, so, the wall lag time is about 6 hours, corresponding to the time taken by the heat flux to reach the inner wall surface and it depends on wall constituents. Consequently, the solar energy stored in the wall contributes to the increase of indoor air temperature by conduction.

3.3.2. Period from 6th April 2010 to 9th April 2010. Unlike the precedent period, Figure 10 shows that the outer wall surface temperature reaches a maximum of $25^{\circ} \mathrm{C}$ on 7 April 2010. This low value is due to the decrease of solar radiation intensity recorded on this period. Here, a same temperature evolution of the two investigated periods was observed. The inner wall surface temperature is always higher than the indoor air temperature which reveals that the heat flux passes from the wall to the room, and like the January period, the lag time is equal to 6 hours. On the cloudy day ( 8 April 2010) the wall temperature is maintained about at $20^{\circ} \mathrm{C}$ and the absence of temperature peak is clear which reveals the wall solar radiation dependence.

3.4. Thermal Analysis. Enhancing conduction through the wall and natural convection heat transfer through the air gap are the keys to improve the thermal efficiency of the passive solar buildings with Trombe walls.

3.4.1. Period from 22nd January 2010 to 25th January 2010. Figure 11 shows the evolution of calculated conductive flux 


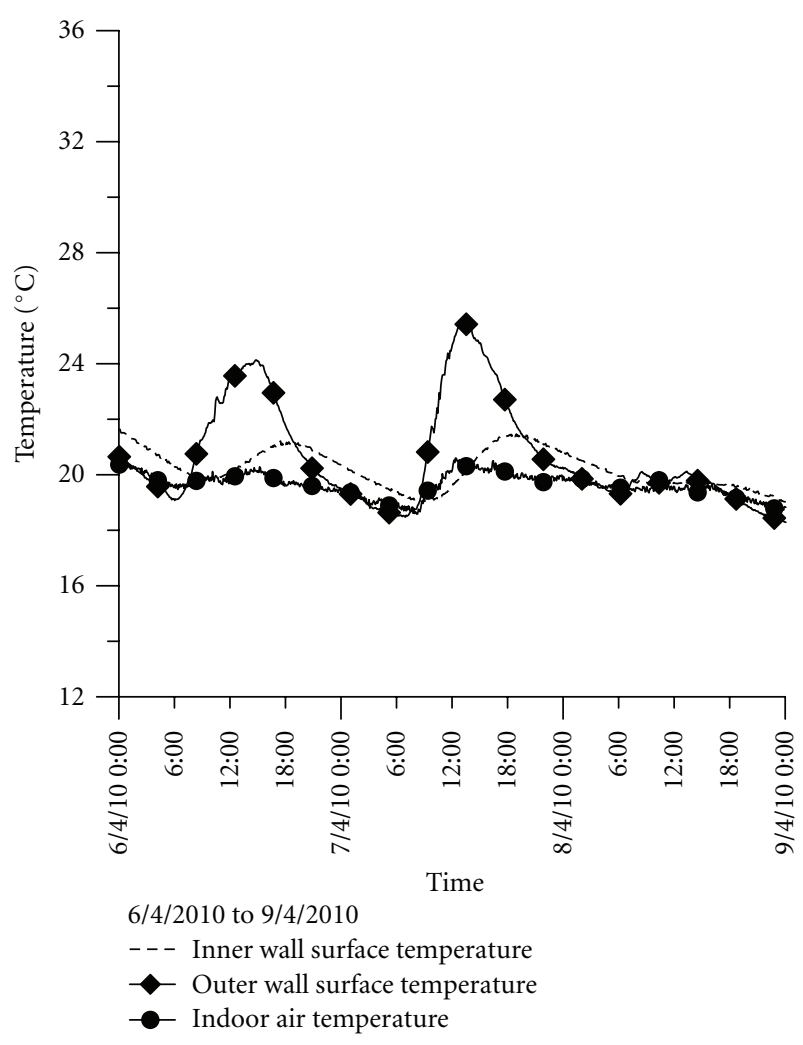

Figure 10: Temperature variations of indoor air temperature and thermal wall surfaces temperatures for April period.

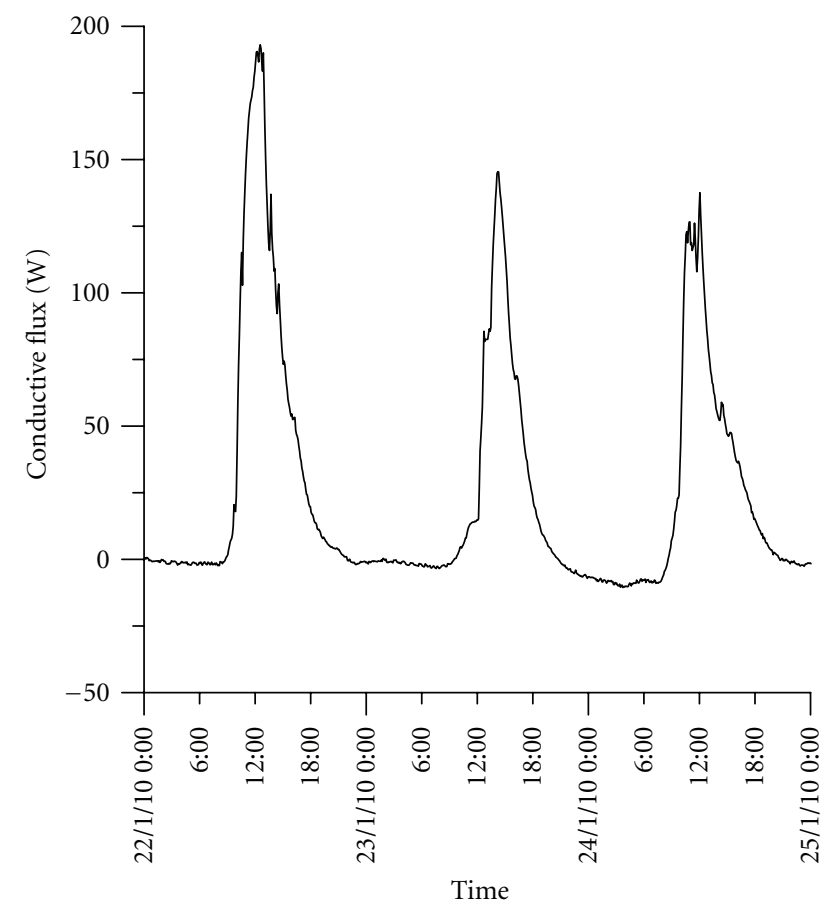

FIGURE 11: Evolution of calculated conductive flux for the period from $22 / 1 / 2010$ to $25 / 1 / 2010$.

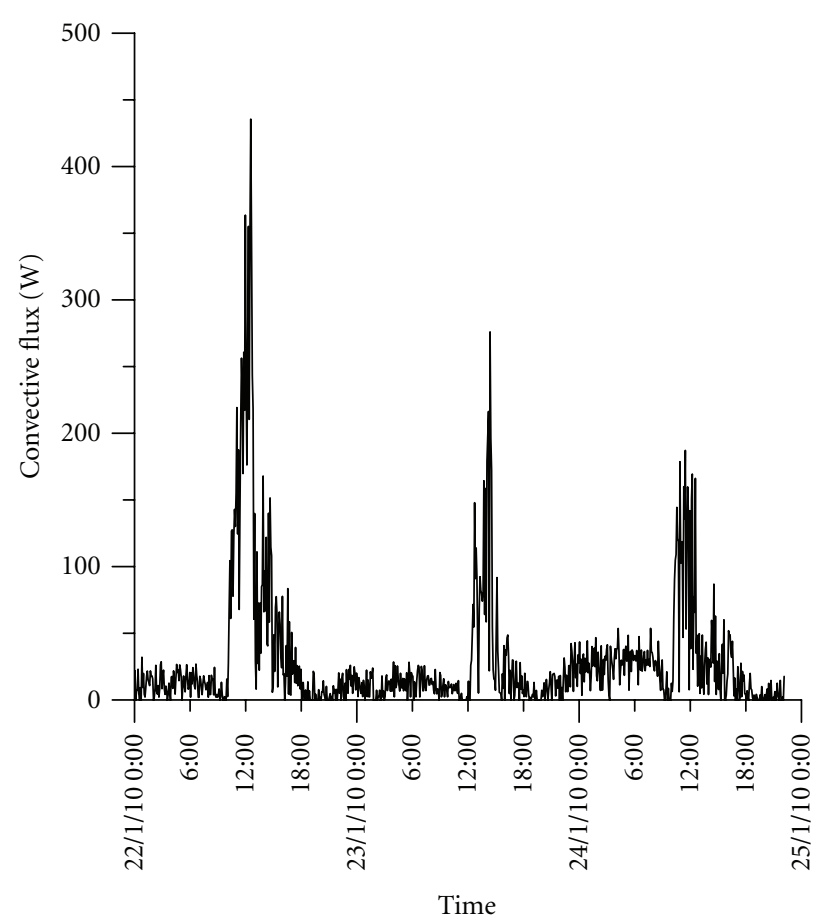

FIGURE 12: Evolution of calculated convective flux for the period from $22 / 1 / 2010$ to $25 / 1 / 2010$.

across the wall according to the experimental data using the wall thermal resistance concept. This flux gives the energy coming into the room after having crossed the massive wall. The absorbed solar energy is transmitted and stored in the wall then, it contributes to the increase of the indoor air temperature by conduction. The instantaneous change in external climatic data affects directly the indoor air temperature and depends on the thermophysical properties of the wall. The maximum value of the conductive flux $188 \mathrm{~W}$ was obtained on 22 January which corresponds to the maximum value of solar radiation $\left(800 \mathrm{~W} / \mathrm{m}^{2}\right)$. Otherwise, on 24 January which is a cloudy day with low sunshine (mean of $400 \mathrm{~W} / \mathrm{m}^{2}$ ) the conductive flux reaches a maximum value of only $175 \mathrm{~W}$. Figure 12 shows the evolution of the calculated convective flux of the period from 22/1/2010 to $25 / 1 / 2010$. On 22 January, the maximum value of convective flux was $430 \mathrm{~W}$. The convective flux values depend on the wall vents air temperature. They provide the air circulation between the wall and the glazing to the room. The thermocirculation process through the air gap affects the indoor air temperature. The main factors influencing on this process are the incident solar radiation intensity, the outside surface temperature of the massive wall, and the velocity of the air through the upper vent.

3.4.2. Period from 6th April 2010 to 9th April 2010. For this period, as mentioned previously that the sun trajectory affected the behavior of the wall on April, Figure 13 shows that the evolution of conductive flux dropped to a maximum of only $70 \mathrm{~W}$ on the sunniest day 7 April 2010 and the calculated convective flux decreased also (Figure 14). The 


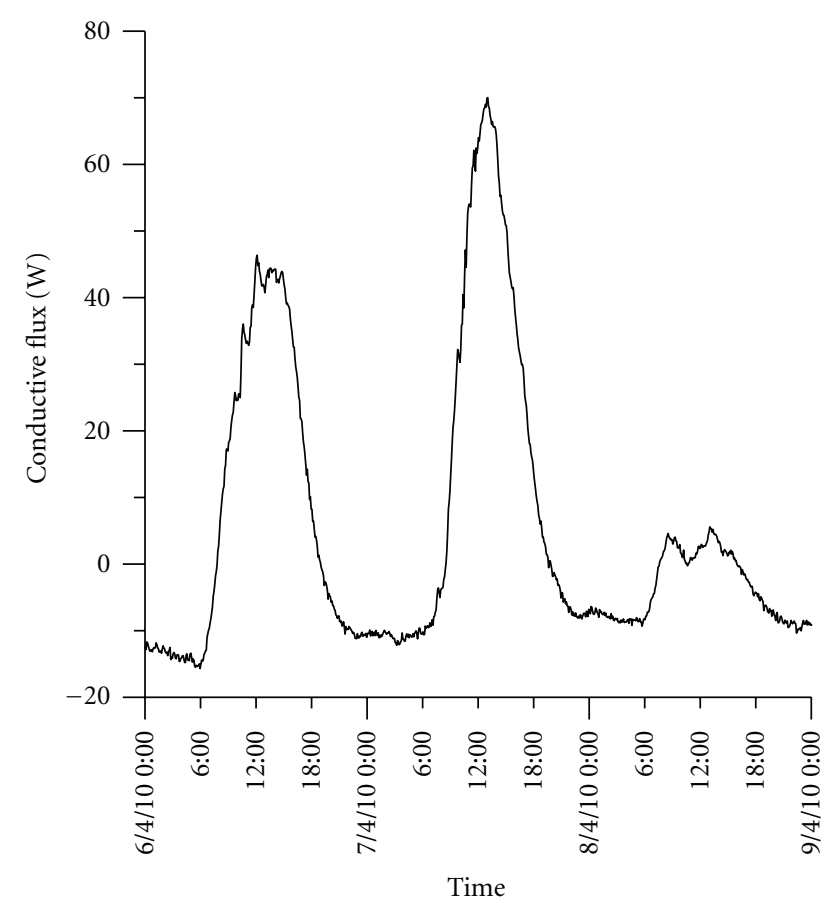

FIGURE 13: Evolution of calculated conductive flux for the period from $6 / 4 / 2010$ to $9 / 4 / 2010$.

wall thermal performance (conductive and convective fluxes) decreases on the cloudy day (8 April 2010) since its operation efficiency is sun dependent.

3.5. Thermal Efficiency. The operating efficiency of Trombe wall is introduced to evaluate the performance of the Trombe wall system. It is defined as a ratio of solar heat gains available from Trombe wall to the total solar heat incident on Trombe wall field during one whole day, and is given by:

$$
\eta=\frac{\text { Heat gain }}{\text { Incident solar heat }} \text {. }
$$

The heat gain comprises the solar heat transferred into the room by conduction through the absorber wall and natural convection by air flow between the indoor air and the air gap.

The operating efficiency of the Trombe wall system on the sunniest day of each period was calculated. The efficiency in April period is only $31.7 \%$, but on January can be up to $45 \%$. Results show that the Trombe wall system can work much more effectively on January than on April, in utilizing solar energy for the sample building, since heat fluxes are strongly influenced by solar radiation amount and sun trajectory.

\section{Conclusion}

In this present investigation, the climatic data, and the thermal performance of the wall were studied for two typical periods one at the beginning and one at the end of winter. The results of this work enable us to draw the following conclusions.

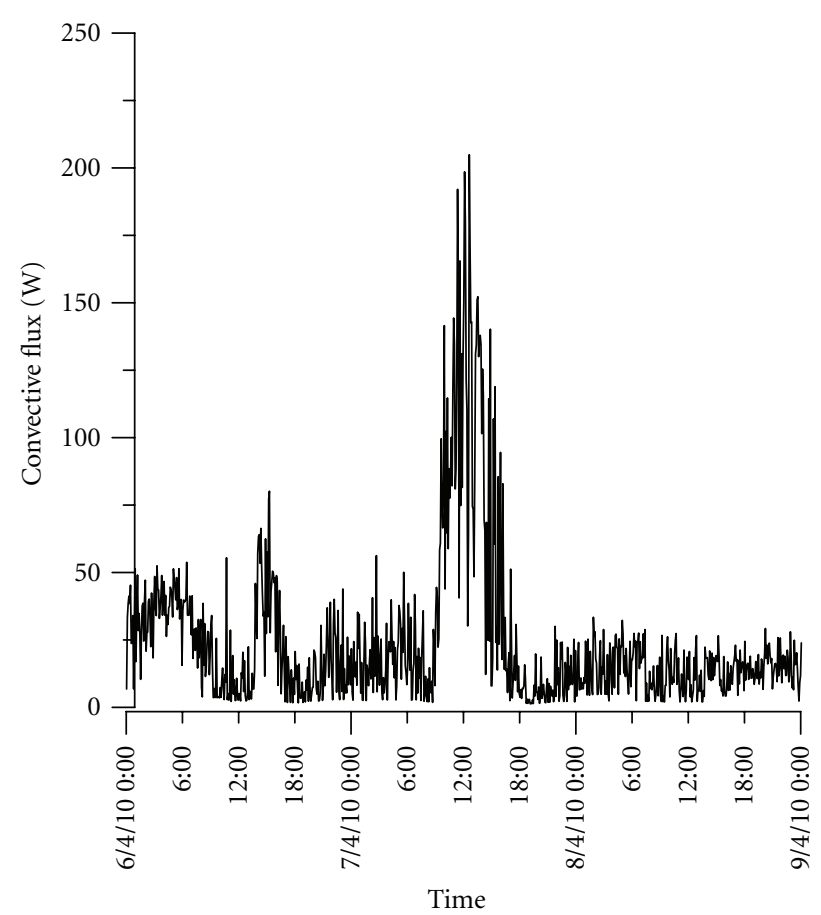

FIGURE 14: Evolution of calculated convective flux for the period from $6 / 4 / 2010$ to $9 / 4 / 2010$.

(i) The experimental results obtained give an indoor air temperature favorable to ensure a good thermal comfort with regard to the outdoor air temperature.

(ii) With vented thermal storage walls, and according to the measurements, the heating transfer to the room is assumed by thermocirculation and conduction of the energy stored in the wall. The wall temperature depends closely on the incident solar radiation. A lag time of 6 hours was observed for the two periods.

(iii) The efficiency of the solar wall decreases from the period of January (45\%) to April period (31.7\%) due to the sun position on the southern façade.

(iv) The use of solar energy consists in profiting from the direct contribution of the solar radiation at the time of the architectural design.

The results obtained for the area of Borj Cedria seem interesting, which makes energy saving potential. The thermal performance of the Trombe wall could be improved by different ways such as increasing the inertia of the building or using new materials for the massive wall to improve its storage ability. Thus, this wall will, therefore, be able to participate in the best possible manner in improving the efficiency for collecting free energy.

\section{References}

[1] E. L. Morse, "Warming and ventilating apartments by sun's rays,” U. S. Patent 246, 1881.

[2] F. Trombe, Maisons solaires, Techniques de l'ingénieur, 1974. 
[3] R. B. Yedder and E. Bilgen, "Natural convection and conduction in Trombe wall systems," International Journal of Heat and Mass Transfer, vol. 34, no. 4-5, pp. 1237-1248, 1991.

[4] J. A. Duffie and W. A. Beckman, Solar Engineering of Thermal Processes, Wiley-Interscience, New York, NY, USA, 2nd edition, 1991.

[5] B. A. Jubran, M. A. Hamdan, and W. Manfalouti, "Modelling free convection in a Trombe wall," Renewable Energy, vol. 1, no. 3-4, pp. 351-360, 1991.

[6] J. Jie, Y. Hua, H. Wei, P. Gang, L. Jianping, and J. Bin, "Modeling of a novel Trombe wall with PV cells," Building and Environment, vol. 42, no. 3, pp. 1544-1552, 2007.

[7] T. G. Özbalta and S. Kartal, "Heat gain through Trombe wall using solar energy in a cold region of Turkey," Scientific Research and Essays, vol. 5, no. 18, pp. 2768-2778, 2010.

[8] W. Smolec and A. Thomas, "Some aspects of Trombe wall heat transfer models," Energy Conversion and Management, vol. 32, no. 3, pp. 269-277, 1991.

[9] J. D. Balcomb, Passive Solar Buildings, The MIT Press, Cambridge, Mass, USA, 1992.

[10] L. Zalewski, M. Chantant, S. Lassue, and B. Duthoit, "Experimental thermal study of a solar wall of composite type," Energy and Buildings, vol. 25, no. 1, pp. 7-18, 1997.

[11] J. Jie, C. L. Luo, W. Sun, H. C. Yu, W. He, and G. Pei, "An improved approach for the application of Trombe wall system to building construction with selective thermo-insulation façades," Chinese Science Bulletin, vol. 54, no. 11, pp. 1949 1956, 2009.

[12] F. Stazi, A. Mastrucci, and C. di Perna, "The behaviour of solar walls in residential buildings with different insulation levels: an experimental and numerical study," Energy and Buildings, vol. 47, pp. 217-229, 2012.

[13] B. K. Koyunbaba, Z. Yilmaz, and K. Ulgen, "An approach for energy modeling of a building integrated photovoltaic (BIPV) Trombe wall system," Energy and Buildings, 2011. In press.

[14] M. Sandbergh and B. Moshfegh, "Investigation of fluid flow and heat transfer in a vertical channel heated from one side by PVelements. Part II. Experimental study," in Proceedings of the World Renewable Energy Congress (WREC' 96), 1996.

[15] J. Hirunlabh, W. Kongduang, P. Namprakai, and J. Khedari, "Study of natural ventilation of houses by a metallic solar wall under tropical climate," Renewable Energy, vol. 18, no. 1, pp. 109-119, 1999. 

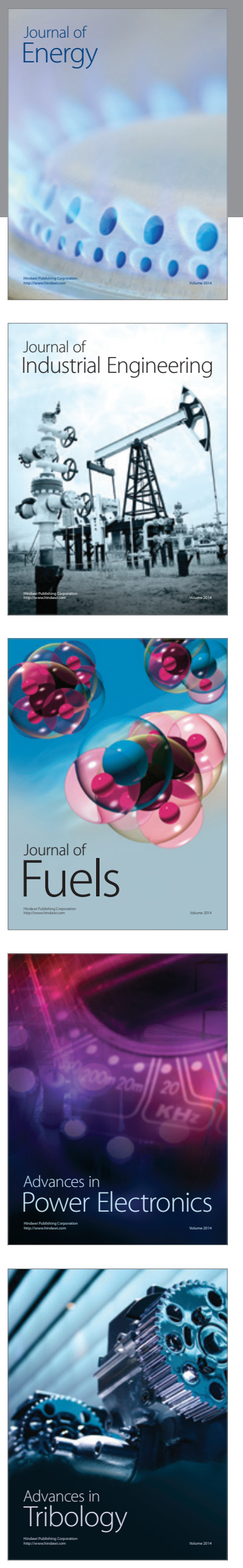
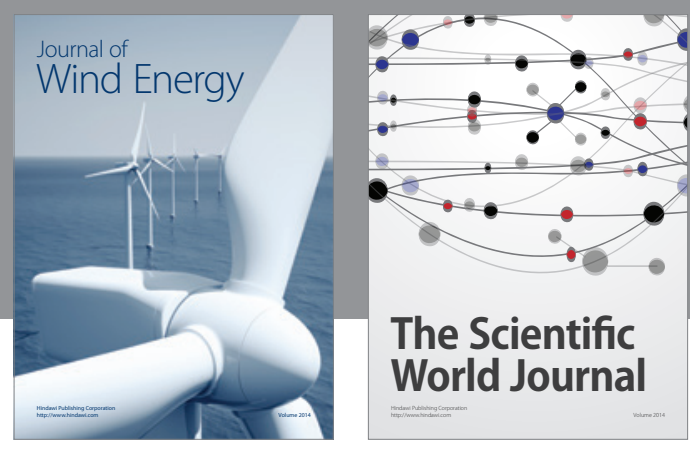

The Scientific World Journal

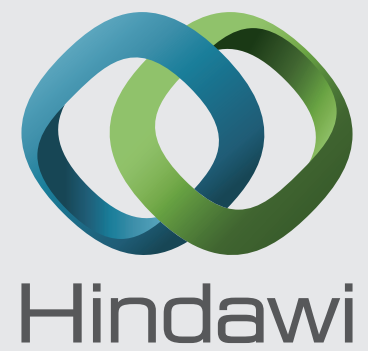

Submit your manuscripts at http://www.hindawi.com
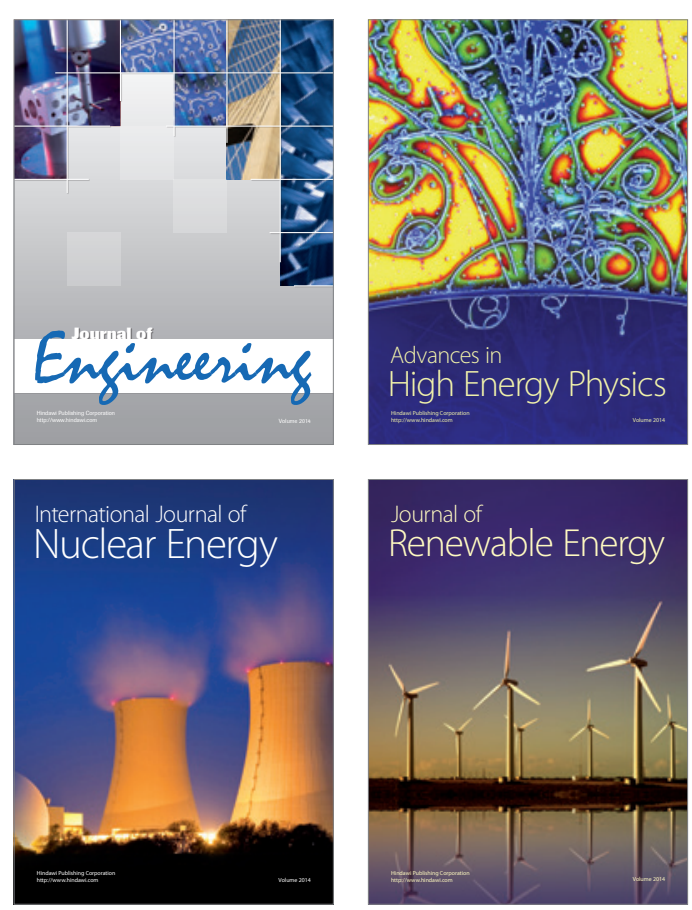

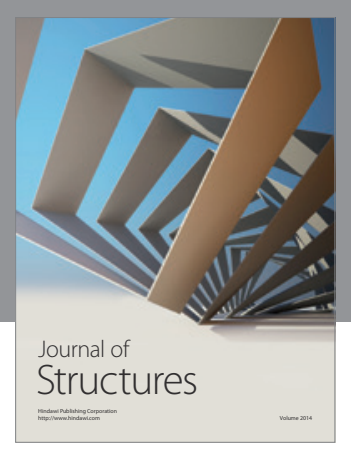

Rotating
Mechinery
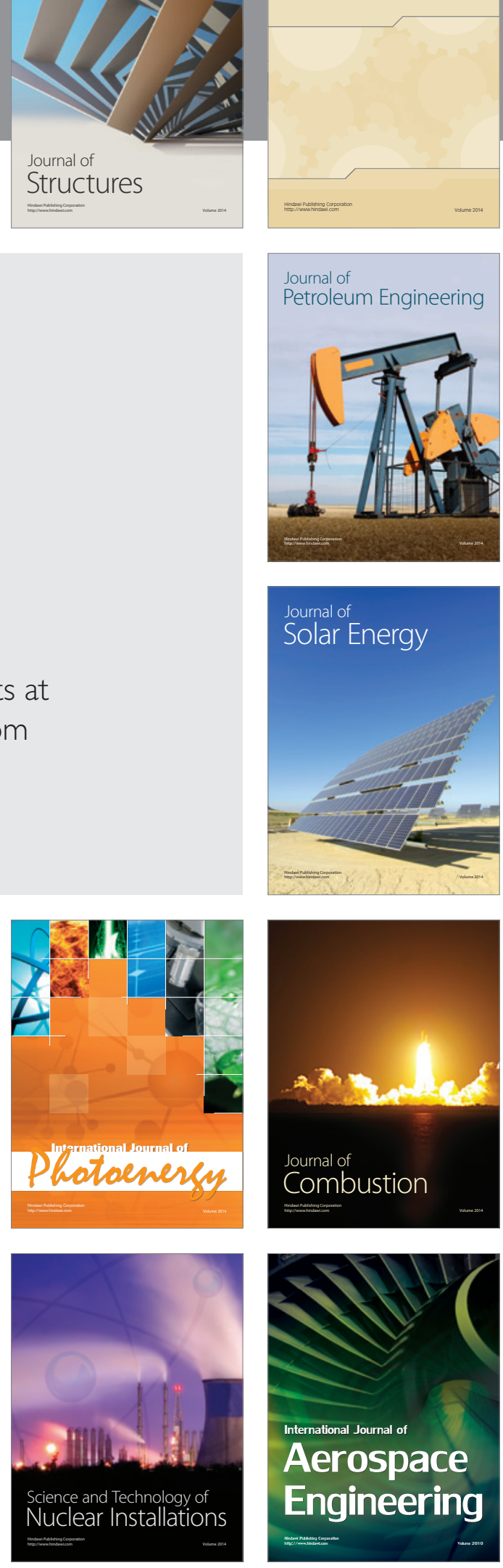